\section{Etiology of cutaneous leishmaniasis and anthropophilic vectors in Juruti, Pará State, Brazil}

\author{
Etiologia da leishmaniose cutânea e vetores \\ antropofílicos em Juruti, Estado do Pará, \\ Brasil
}

\footnotetext{
1 Seção de Parasitologia, Instituto Evandro Chagas, Ananindeua, Brasil. 2 Centro de Ciências Biológicas e da Saúde, Universidade do Estado do Pará, Belém, Brasil. 3 Departamento de Controle de Endemias/Gerência Técnica das Leishmanioses, Secretaria de Estado de Saúde Pública do Pará Belém, Brasil. 4 Núcleo de Medicina Tropical, Universidade Federal do Pará, Belém, Brasil.

5 Instituto de Biociências, Universidade de São Paulo, São Paulo, Brasil.

6 Instituto de Ciências Biomédicas, Universidade de São Paulo, São Paulo, Brasil.

Correspondence

L. M. Garcez

Seção de Parasitologia,

Instituto Evandro Chagas.

BR $316 \mathrm{~km} 07$ s.n.,

Ananindeua, $P A$

67030-000, Brasil.

lourdesgarcez@iec.pa.gov.br
}

Abstract

\author{
Lourdes Maria Garcez 1,2 \\ Daniela Cristina Soares 1,3 \\ Anadeiva Portela Chagas 1 \\ Gilberto César Rodrigues de Souza 1 \\ Jefferson Francisco Correia Miranda ${ }^{1}$ \\ Habib Fraiha 4 \\ Lucile Maria Flöeter-Winter 5 \\ Heloísa Marceliano Nunes 1 \\ Ricardo Andrade Zampiere 5 \\ Jeffrey Jon Shaw 6
}

\section{Introduction}

In a preliminary study in Juruti, a mining municipality in western Pará State, Brazil, 12 out of 21 patients suspected of presenting cutaneous leishmaniasis showed positive PCR (SSUrDNA and G6PD): Leishmania (Viannia) braziliensis (9/12; 75\%) and L. (V.) sp. (3/12; 25\%). Entomological studies in the same location revealed the presence of 12 different phlebotomine species ( $n=$ 105). One of the most common species was Lutzomyia (Psychodopygus) complexa (17\%) which is both highly anthropophilic and a known vector of $\mathrm{L}$. (V.) braziliensis in other regions of Pará. These preliminary findings should serve to guide future epidemiological surveillance in Juruti.

Cutaneous Leishmaniasis; Leishmania; Polymerase Chain Reaction; Entomology
In the State of Pará, Brazil, there are seven Leishmania species that cause cutaneous leishmaniasis in humans. Two are associated with severe forms of the disease: Leishmania (Viannia) braziliensis (mucocutaneous) and Leishmania (Leishmania) amazonensis (diffuse cutaneous) 1. Etiological diagnosis of cutaneous leishmaniasis helps clarify local epidemiology and is essential for the clinical management in cases of reactivation ${ }^{2}$. Such information, associated with entomological surveillance, is particularly important for controlling the disease in vulnerable areas 1 . Thus, during an epidemiological survey in the mining municipality (county) of Juruti in western Pará State, etiological diagnosis was performed for cutaneous leishmaniasis using PCR (polymerase chain reaction) in patients with suspicious lesions treated at the Francisco Barros Municipal Hospital, and anthropophilic species of sylvatic phlebotomines were investigated in a mining area with surviving forest cover.

\section{Material and methods}

The study was approved by the Institutional Review Board of the Evandro Chagas Institute (research protocol no. 0029/2007). 


\section{Diagnosis}

Skin biopsies were taken from the edge of lesions in 21 individuals with suspicion of cutaneous leishmaniasis at the Francisco Barros Municipal Hospital in Juruti (February to June 2007). The following diagnoses were performed: clinical, parasitological (Giemsa-stained smear/isolation in NNN medium), molecular (PCR), and Montenegro skin test 3 . DNA was extracted from the samples with phenol/chloroform ${ }^{4}$. PCR used oligonucleotides based on the Leishmania SSUrDNA and G6PD genes, which jointly discriminate genus, sub-genera Leishmania and Viannia, and the species L. (V.) braziliensis 5 . In PCR-SSUrDNA, the reaction occurred in a thermocycler (Eppendorf Mastercycler Gradient; Eppendorf, Hamburg, Germany) under the following conditions: mix $50 \mu \mathrm{L}$ (Taq DNA polymerase $0.02 \mathrm{U} / \mu \mathrm{L} ; \mathrm{MgCl}_{2} 2.0 \mathrm{mM}$; dNTPs $0.2 \mathrm{mM}$; KCl Fermentas EP401; primers S4, S12, S17, and S18 $0.2 \mathrm{mM}$ each; sample $2.0 \mu \mathrm{L}$ ); denaturation $\left(94^{\circ} \mathrm{C} / 5^{\prime}\right)$; annealing $\left(30 \times 94^{\circ} \mathrm{C} / 1^{\prime}\right)$; extension ( $\left.72^{\circ} \mathrm{C} / 45^{\prime} ; 72^{\circ} \mathrm{C} / 10^{\prime}\right)$. Nested PCR (S17 and S18) was performed with the product under the same conditions. Similar procedures were adopted with the PCR-G6PD, with the added mixture of dimethyl sulfoxide $(2.5 \mu \mathrm{L})$ to a final concentration of $5 \%$. In addition, the first stage was specific for subgenus Viannia (ISVA/ISVC), differing the annealing temperature (AT), $60^{\circ} \mathrm{C}$, and extension time (30"). The amplified product $(1 \mu \mathrm{L})$ was used in the following stage for the two semi-nested PCR reactions, which identified the non-L. (V.) braziliensis subgenus Viannia (ISVG/ISVC, AT $68^{\circ} \mathrm{C}$ ) and species L. (V.) braziliensis (ISVB/ISVC, AT $67^{\circ} \mathrm{C}$ ). The amplified DNA was separated by agarose gel electrophoresis $(1.5 \%$ in tris-acetate $40 \mathrm{mM} /$ EDTA $1 \mathrm{mM}$ ) with ethidium bromide $(5 \mu \mathrm{L}, 10 \mathrm{mg} / \mathrm{mL})$ and viewing under ultraviolet light. Controls were used with different species of Leishmania (50ng/mL) and distilled water, in addition to the molecular weight marker (100 base pairs, Invitrogen). Polymorphisms that discriminated $L$. (L.) amazonensis, $L$. (L.) infantum chagasi, and L. (Viannia) sp. were investigated in negative samples for $L$. (V.) braziliensis after sequencing the products of the nested PCRUSSrDNA bound to the TA Cloning 2.1 vector (Invitrogen, Carlsbad, USA) and cloned in DH5 $\alpha$ bacteria, according to the protocol for the Big Dye Terminator v. 3.1 kit (Applied Biosystems, Warrington, UK). Sequencing was used to investigate whether the samples' negativity according to ribosomal PCR (PCR-SSUrDNA) was sufficient to confirm positivity for subgenus Viannia. The genetic analyzer ABI PRISM (Hitachi) was used, and the sequences were aligned with BioEdit
(Tom Hall, North Carolina State University, http://www.mbio.ncsu.edu/BioEdit/bioedit. html) 6 .

\section{Entomological surveys}

Two entomological surveys were conducted in January 2008 in different regions of the municipality, both in the forest around the Capiranga mining base in Juruti, located at S02.30'28.3" W056'11'01.0" and S02028'32.9" W056 ${ }^{\circ} 12^{\prime} 45.6^{\prime \prime}$. Shannon light traps were used (at 18:00 and 20:00 hours), and the phlebotomines were identified using the morphological method 7.

\section{Results}

\section{Diagnosis}

Of the 21 cases with clinical suspicion of cutaneous leishmaniasis, 12 were diagnosed based on the presence of DNA from genus Leishmania (57\%), of which 11 (52\%) were parasitologically confirmed by direct microscopy. Nine of the 12 (75\%) had amplified products for subgenus $V i$ annia and species L. (V.) braziliensis (G6PD), as shown in Figure 1, and the other three (25\%) did not show amplification for subgenus Viannia. Sequencing of the products generated from these three samples confirmed that they belonged to subgenus Viannia.

In the $9 / 12(75 \%)$ patients with positive results for L. (V.) braziliensis, all confirmed by parasitology, there were delayed hypersensitivity reactions to the Montenegro antigen, with diameters varying from $7 \mathrm{~mm}$ to $40 \mathrm{~mm}$ (16.3 \pm 3.2). Time since onset of the disease (as reported by the patients themselves) ranged from 1 to 4 months $(1.6 \pm 0.3)$.

\section{Entomological survey}

A total of 105 sylvatic phlebotomines were captured, belonging to 12 species, as follows: (1) Lutzomyia (Psychodopygus) geniculata (22\%), (2) Lu. (P.) paraensis (20\%), (3) Lu. (P.) complexa (17\%), (4) Lu. (Nyssomyia) flaviscutellata (13\%), (5) Lu. (P.) davisi (10\%), (6) Lu. (P.) amazonensis (6\%), (7) Lu. (P.) chagasi (5\%), (8) Lu. (N.) richardwardi (4\%), (9) Lu. (P.) carrerai carrerai (1\%), (10) Lu. (P.) llanosmartinsi (1\%), (11) Lu. (P.) longispina (1\%), and (12) Lu. (T) ubiquitalis (1\%). None of the specimens were naturally infected with Leishmania. 
Figure 1

PCR-G6PD products developed in agarose gel (1.5\%) for etiological diagnosis of cutaneous leishmaniasis

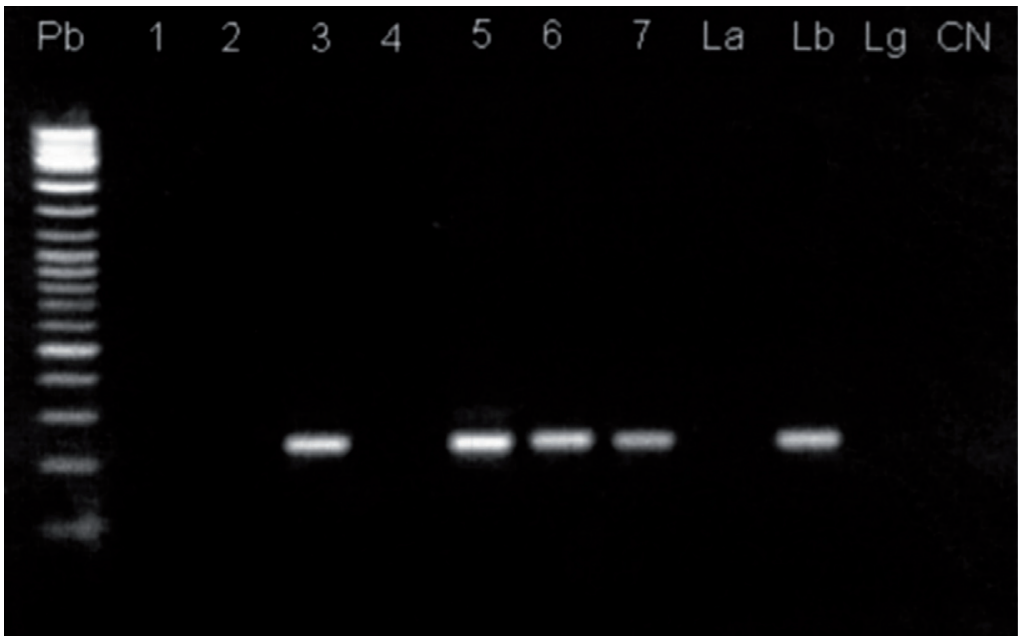

Pb: marker 100bp; La, Lb, and Lg: L. (L.) amazonenisis, L. (V.) braziliensis, and L. (V.) guyanensis; CN: negative control (water). Note: the analysis used DNA extracted from skin biopsies from the edge of patients' lesions. The specific band for $L$. (V.) braziliensis displays 234 base pairs (columns 3, 5, 6, 7, and Lb). Columns 1, 2, and 4 correspond to non-amplified samples (individual without leishmaniasis).

\section{Discussion}

Etiological diagnosis by PCR assists in determining the prognosis and appropriate therapy, which vary according to the parasite's species or strain ${ }^{8}$. In this study, the majority of the positive individuals for cutaneous leishmaniasis were infected with $L$. (V.) braziliensis (9/12, 75\%), clearly differentiated from other Amazonian species by PCR-G6PD (Figure 1). This finding was consistent with direct microscopic examination, as well as by the high rate of positive reactions to the Montenegro antigen and the extensive diameter of the skin reactions ${ }^{9}$. Despite recent advances in the production of primers 10 , new oligonucleotides are still needed to detect polymorphisms that discriminate Amazonian species of non- $L$. (V.) braziliensis subgenus Viannia using PCR, as well as to optimize PCR-G6PD procedures in order to eliminate the need for cloning.

Entomological surveillance in risk areas for cutaneous leishmaniasis is important for analyzing the epidemiological conditions for transmission, as well as to provide the basis for control measures 1 . The forest area around the bauxite mine showed a heavy presence of the vectors for L. (L.) amazonensis, $L u$. (N.) flaviscutellata, with low anthropophilia, and for $L$. (V.) braziliensis, $L u$. (P.) complexa, highly anthropophilic. The latter is capable of biting humans avidly in broad daylight and even at high noon, and outside the forest, in addition to its extraordinary population density during the cooler season in the Amazon. Such characteristics, combined with its susceptibility to Leishmania infection, make this species a prime vector for the disease 11 . In the 1960s and 70s, when highways were opened for a mining project in Serra dos Carajás, Pará, the incidence of cutaneous leishmaniasis was estimated at one case per kilometer of highway built, with the majority of cases transmitted by $L u$. (P.) complexa 12 . The daytime habits of this species, rare among Amazonian phlebotomines, increase the risk of human exposure to infection, thus explaining the high number of reported cases due to $L$. (V.) braziliensis in the sample studied in Juruti.

The knowledge generated by this research will be incorporated into health education activities in Juruti, but further studies are still needed to elucidate the epidemiology of cutaneous leishmaniasis and provide better backing for local control measures. 


\section{Resumo}

Em um estudo preliminar em Juruti, um município minerário na região oeste do Estado do Pará, Brasil, 12 de 21 pacientes suspeitos de possuírem leishmaniose cutânea tiveram PCRs positivas (SSUrDNA e G6PD): Leishmania (Viannia) braziliensis (9/12; 75\%) $e$ Leishmania (Viannia) $s p$. (3/12; 25\%). Estudos entomológicos na mesma localidade revelaram a presença de 12 diferentes espécies de flebotomíneos $(n=105)$. Uma das espécies mais comuns foi Lutzomyia (Psychodopygus) complexa (17\%) que é altamente antropofílica e reconhecida vetora de $\mathrm{L}$. (V.) braziliensis em outras regiões do Estado do Pará. Esses resultados preliminares servem como orientação para futura vigilância epidemiológica em Juruti.

Leishmaniose Cutânea; Leishmania; Reação em Cadeia da Polimerase; Entomologia

\section{Contributors}

L. M. Garcez participated in preparing the research proposal, fundraising, coordination, student supervision, and drafting of the manuscript. D. C. Soares collaborated with support for patient treatment, sample collection, molecular tests, and drafting of the manuscript A. P. Chagas participated in the study's methodological design, data acquisition (entomological captures, identification of phlebotomines), analyses, and critical revision of the manuscript with an intellectual contribution and revision after acceptance for publication. G. C. R. Souza collaborated in the entomological data acquisition (entomological captures, identification of phlebtomines), analyses, and critical revision of the manuscript with an intellectual contribution and revision after acceptance for publication. J. F. C. Miranda contributed to the data acquisition on the etiology of human cutaneous leishmaniasis (sample, diagnostic tests), analyses, interpretation of the results, and critical revision of the manuscript with an intellectual contribution and revision after acceptance for publication. H. Fraiha participated in the methodological design of the entomological study, data acquisition (identification of phlebotomines), analyses, interpretation of the entomological results, and revision of the manuscript (entomology) before and after acceptance for publication. L. M. Flöeter-Winter contributed to the methodological design of the research on the etiology of human cutaneous leishmaniasis with an emphasis on the molecular diagnosis strategy, analysis, interpretation of the results, and revision of the manuscript (molecular diagnosis) before and after acceptance for publication. H. M. Nunes participated in the acquisition, analysis, and interpretation of clinical and epidemiological data and the critical revision of the manuscript with an intellectual contribution and revision after acceptance for publication. R. A. Zampiere collaborated in the data acquisition on the etiology of human cutaneous leishmaniasis (molecular diagnosis), analyses, interpretation of the results, and critical revision of the manuscript with an intellectual contribution and revision after acceptance for publication. J. J. Shaw participated in the methodological design, contributed to the drafting of the manuscript, analyses, and critical revision of the manuscript with an intellectual contribution and revision after acceptance for publication.

\section{Acknowledgments}

The authors wish to thank ALCOA Alumínio S/A, Brazilian Council for Scientific and Technological Development (CNPq), Department of Science and Technology/Secretariat of Science, Technology, and Strategic Inputs/Ministry of Health (DECIT/ SCTIE/MS), and Coordination for the Improvement of Higher Education Personnel (CAPES) for the research funding and the Juruti Municipal Health Secretariat, Pará State. 


\section{References}

1. Secretaria de Vigilância em Saúde. Manual de controle da leishmaniose tegumentar americana. Brasília: Ministério da Saúde; 2007.

2. Costa JML, Lago EL, Magalhães AV, Marsden PD. Leishmaniose recidiva cútis causada por Leishmania (Viannia) braziliensis. An Bras Dermatol 1996; 7:329-33.

3. Shaw JJ, Lainson R. Leishmaniasis in Brazil: X. Some observations on intradermal reactions to different trypanosomatid antigens of patients suffering from cutaneous and mucocutaneous leishmaniasis. Trans R Soc Trop Med Hyg 1975; 69: 323-35.

4. Uliana SR, Affonso MH, Camargo EP, Flöeter-Winter LM. Leishmania: genus identification based on a specific sequence of the $18 \mathrm{~S}$ ribosomal RNA sequence. Exp Parasitol 1991; 72:157-63.

5. Castilho TM, Shaw JJ, Flöeter-Winter LM. New PCR assay using glucose-6-phosphate dehydrogenase for identification of Leishmania species. J Clin Microbiol 2003; 41:540-6.

6. Hanahan JJ, Bloom FR. DNA cloning: a practical approach. Techniques for transformation of E. coli. 2nd Ed. Oxford: IRL Press; 2002.

7. Yong DG, Duncan MA. Guide to the identification and geographic distribution of Lutzomyia sandflies in Mexico, the West Indies, Central and South America (Diptera: Psychodidae). Gainsville: American Entomological Institute; 1994. (Memoirs of the American Entomological Institute, 54).
8. Rotureau B, Ravel C, Nacher M, Couppie P, Curtet I, Dedet J, et al. Molecular epidemiology of Leishmania (Viannia) guyanensis in French Guiana. J Clin Microbiol 2006; 44:468-73.

9. Andrade MS, Brito MEF, Silva ST, Lima BS, Almeida EL, Albuquerque EL, et al. Leishmaniose tegumentar americana causada por Leishmania (Viannia) braziliensis, em área de treinamento militar na Zona da Mata de Pernambuco. Rev Soc Bras Med Trop 2005; 38:229-33.

10. Marcussi VM, Marcussi LM, Barbosa-Tessmann IP, Lonardoni MVC, Silveira TGV. Leishmania (Viannia) braziliensis: new primers for identification using polymerase chain reaction. Exp Parasitol 2008; 120:300-5.

11. Fraiha H, Shaw JJ, Lainson R. Phlebotominae brasileiros - II. Psychodopygus wellcomei, nova espécie antropofílica de flebótomo do grupo Squamiventris, do sul do estado do Pará, Brasil (Diptera, Psychodidae). Mem Inst Oswaldo Cruz 1971; 69:489-500.

12. Ward RD, Shaw JJ, Lainson R, Fraiha H. Leishmaniasis in Brazil. 8. Observations on the phlebotomine fauna of an area highly endemic for cutaneous leishmaniasis, in the Serra dos Carajas, Pará State. Trans R Soc Trop Med Hyg 1973; 67:174-83.

Submitted on 20/Mar/2009

Final version resubmitted on 12/Jun/2009

Approved on 24/Jun/2009 